Available online: https://journals.researchsynergypress.com/index.php/ijebce/

International Journal of Entrepreneurship, Business and Creative Economy (IJEBCE)

ISSN 2775-3085 (Online) | 2775-3107 (Print)

Volume 1 Number 2 (2021): 45-53

\title{
Are people in Ifugao Philippines Entrepreneurship? Shedding Light on Entrepreneurial Characteristics, Motivations, Challenges, and Intentions among Ifugao
}

\author{
Client William Malinao ${ }^{1}$ \\ ${ }^{1}$ Ifugao State University, Philippines
}

\begin{abstract}
Entrepreneurship is a means of beginning your own company. A person's target and option depend on those processes of thought. These cycles of thinking and motives either drive or drag the participant to the creative exercises. To fill the gap in the literature, this research explored the entrepreneurial traits, motives, difficulties, and obstacles faced by Ifugao citizens in the Philippines while doing business. The relationship between the above variables and the entrepreneurial aspirations of Ifugao individuals was also calculated. Data were collected from 263 Ifugao persons, both beneficiaries and non-beneficiaries of the programs of various government agencies in the province using the snowball sampling process, through a research questionnaire and semistructured interview. Using means, the Mann-Whitney U test, and the rank order correlation of Spearman, this paper finds that considering the difficulties and obstacles they face, Ifugao individuals retain the character of becoming an entrepreneur. Overall, five traits that are common to respondents have been identified. Ifugao people stay inspired and it motivates them to persevere constantly in carrying out entrepreneurial practices. Finally, the findings of this study indicate that training, seminars, and workshops, the positive perceived image of entrepreneurs, and motives have a major impact on the entrepreneurial purpose of Ifugao people, which is important for entrepreneurial success.
\end{abstract}

Keywords: Entrepreneurial Characteristics; Motivations; Challenges, Entrepreneurial Intentions; Ifugao People, Philippines

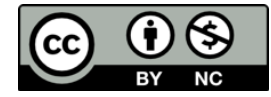

This is an open access article under the CC-BY-NC license.

\section{INTRODUCTION}

The new economic driver of any economy is entrepreneurship. It is necessary for economic growth and essential for the owners of businesses to generate and increase profits and provide a return on investment. The backbone of economic growth has been known to be entrepreneurship. It has been well-founded that, to a large extent, the degree of economic development of a country depends on the level of the region's entrepreneurial activities. In many nations, business activity is the key to development and prosperity (Lv et al. 2011).

Ideally, an entrepreneur is someone who plays an important role in a country's economic growth. Entrepreneurs can be considered as a person who has the initiative, capacity, and drive to set up his own business or company and who is always looking for high achievement. They are a social impact catalyst who works for the common good. They are searching for possibilities, discovering them, and seizing them primarily for economic gains. Entrepreneurs can articulate and execute the desire, skill; inspiration, and creative ability to create a company or industry of his own. Their goal is to gain profit by manufacturing or selling products or services that are socially Corresponding author Client William Malinao, clint13william@gmail.com 
International Journal of Entrepreneurship, Business and Creative Economy (IJEBCE), Vol. 1 (2), 45-53

Are people in Ifugao, Philippines Entrepreneurial? Shedding light on entrepreneurial characteristics, motivations, challenges, and intentions among Ifugao

Client William Malinao

beneficial. They are enriched by the intrinsic qualities of adventurism, the ability to face risks, the desire to innovate, and imagination and is ready to make dynamic improvements in the manufacturing process, to incorporate technologies, and to find new uses for raw materials (Kanchana, 2013).

People are bound to have strengths and weaknesses as an entrepreneur. That is the greater reason why an entrepreneur wants to mask his vulnerabilities (2). And, to overcome these vulnerabilities, basic education and ongoing on-the-job investment are therefore essential for the development of entrepreneurial skills. Entrepreneurship skills are vital to the company's creation and survival (Amatori, 2016). Although there is no blueprint for becoming a successful entrepreneur, entrepreneurial success is correlated with certain skills and characteristics. Skills are, therefore, the knowledge displayed in some circumstances by acts or a specific result. Skills are gained and improved by training (Zehra, 2016).

Lagawe, Ifugao is a municipality of the fourth class and the capital of Ifugao Province in the Cordillera Administrative Region. Lagawe, Ifugao, with God-loving and inspired citizenship, is working for a better business hub in Cordillera, Philippines, living in an environmentally balanced and prosperous environment, improving and cultivating a sensitive and resilient business community under the stewardship of local governance. Ifugao State University, with its extension programs and services, and the Department of Trade and Industry, in collaboration with the Local Government Unit of Lagawe, are making efforts within the municipality to promote and track programs empowering local entrepreneurs and businesses in the town. Nevertheless, for Ifugao Chapter, there are only 43 companies from the Philippine Chamber of Commerce and Industry. In Lagawe, Ifugao, there is a business or market day transaction plan for Lagawe, Ifugao (Saturday, Tuesday, and Thursday). This shows that companies in the city are still on the road to growth (See, 2015).

There is a current competitiveness indicator framework in the Philippines that is used as guidance to shape the structure behind the Index. Local economic growth and competitiveness at regional, national and global levels are incorporated into the system. It can be noted that when grouped according to municipality classification, the municipality ranked 116th and 114th on local economic growth and business presence, respectively (Cities and Municipalities Index, 2019). The number of micro-enterprises in each barangay initiated by the DTI and LGU is slowly dying concerning the results provided by the competitive index for 2019. In the study conducted by Ifugao State University, extension program beneficiaries have modest participation. While attempts are carried out, the continuity of programs is still fading. Given the government's interventions with its member institutions, the new venture's failure rate should not be overlooked (Dugyon, 2016). Despite programs to mitigate ignorance is running a company, still entrepreneurs face growth obstacles. Despite the efforts made, in recent years the number of failed businesses has not decreased (Fong, 2016). Therefore, this research seeks to uncover the reasons behind the city's limited business transactions. This research aimed to assess the entrepreneurial side of Ifugao individuals. This would be a good starting point to assess if they are actually in the business sector. Specifically, this study aims to uncover the entrepreneurial characteristics, motives, problems and challenges, the perceived image of entrepreneurs, and the business intentions of Ifugao individuals. Behind the small number of entrepreneurs in Lagawe, Ifugao, this research could dig deeper into the root cause. This research would make it possible for the government agencies to determine the programs to be extended to the entrepreneurs. Finally, in the research literature, the existence of Ifugao people on entrepreneurship is considered a missing item, which is the field that has not yet been explored. The conduct of this study is, therefore, considered important.

\section{LITERATURE REVIEW}

The main driver in economic growth is the development of entrepreneurship (Kanchana et al. 2013). The strategic advantage of an organization comes from its creative talents, managerial 
International Journal of Entrepreneurship, Business and Creative Economy (IJEBCE), Vol. 1 (2), 45-53

Are people in Ifugao, Philippines Entrepreneurial? Shedding light on entrepreneurial characteristics, motivations, challenges, and intentions among Ifugao

Client William Malinao

experience, technological know-how, and adaptability to its managers/owners' internal and external market environments. It is now well known that entrepreneurs can be created and nurtured through effective initiatives in the form of entrepreneurship skills learning programs through the fallacy that entrepreneurs are born (Bosire \& Nzaramba, 2018). Harper, 2003). According to studies, entrepreneurs must have some distinctive features, behaviors, and principles to be competitive in the world of business that offers an incentive for them and separate them from others. Entrepreneurs have to be devoted to what they do.

Entrepreneurs need to be self-reliant, concentrated on the opportunity, able to take chances, and need to prosper in competition. According to the research undertaken by famous authors, the attributes capable of reflecting the entrepreneurial actions of individuals are the need for success, locus of control, risk-taking tendency, tolerance for uncertainty, innovativeness, and self- confidence. An entrepreneur must be sufficiently creative to produce new technologies or new quality products, to develop new manufacturing processes, to reach a new market, to create a new source of supply, or to establish a new organization or company structure. An entrepreneur must also have a deep need to do something, who, with their initiative, tries to solve challenges themselves, set expectations and aim for these goals, display a higher success in difficult tasks, and be creative in the sense of searching for fresh and improved ways to enhance their performance (Gurol \& Atsan, 2006). Another is that entrepreneurs need not be averse to risk-taking. In general, entrepreneurs are described as being more likely to take chances than other groups (Entrialgo et al. 2000).

For the aforementioned example, it is more possible for a company to prosper further if business owners will have ample entrepreneurship expertise, interest, and capabilities in running a business. These skills support start-ups and are also beneficial during a company's life cycle. The role of an entrepreneur in the growth of an economy can thus not be overlooked. The growth of an organization, therefore, depends on the development of the skills necessary to carry out a smooth running of day-to-day business operations. The biggest hurdle to economic development, though, is also the lack of dynamic entrepreneurs who can introduce markets and processes to promote economic growth (Abdul, 2018).

In the Philippines, to resolve the issue, the Commission on Higher Education (CHED) has required universities and colleges to expand their educational and civic services to the communities. The social duty of state universities and colleges is to educate communities and improve lives through the transmission of information and technology through instruction, conferences, lectures, and professional advice (Dugyon, 2016). Also, in cooperation with the local government unit, the Department of Trade and Industry is accountable for the country's objective of an internationally competitive and creative industry and services that lead to sustainable development and job creation. Programs from continuous learning to supervision and assistance are then built to keep the company competitive both locally and internationally.

\section{RESEARCH METHOD}

\section{Design}

With the subjects of the paper, using the mixed approach, both quantitative and qualitative, was more effective. Through this method the understanding of entrepreneurial issue in Ifugao will be more enriched and the result from the quantitative analysis can be verified during the qualitative 
International Journal of Entrepreneurship, Business and Creative Economy (IJEBCE), Vol. 1 (2), 45-53

Are people in Ifugao, Philippines Entrepreneurial? Shedding light on entrepreneurial characteristics, motivations, challenges, and intentions among Ifugao

Client William Malinao

analysis. Among the styles of Quantitative Research Design, three were correctly applied to examine the goals of the analysis and address the hypotheses: Descriptive, Comparative, and Correlational Research. And to verify the information obtained in the descriptive process, qualitative design was used to generate more detailed and practical data through personal interviews. The investigator, therefore, used a questionnaire and a semi-structured interview.

\section{Data}

Non-beneficiaries and recipients of DTI/LGU/IFSU Extension programs for the year 2019 were respondents to the report. DTI was not, however, able to supply the data requested last September 21,2019 . In this analysis, a snowball sampling design was used to assess the unknown population size. The researcher used a modified questionnaire in a close-ended form using the 4-point Likert scale to collect relevant data for defined research problems, given the number of populations covered under this analysis. The questionnaire developed was tested for validity and reliability. Two sets of questionnaires were prepared during this review. For the non-beneficiaries, one was for the beneficiaries of the 2019 DTI/LGU/IFSU Extension programs. A total of 263 Ifugao people served as the respondents of the study. The instrument consisted of multiple parts responding to the study's problems. The research instrument test was performed as a preliminary test with entrepreneurs from Kiangan and Lamut, Ifugao, for the final version of the questionnaire. Via Cronbach alpha, the reliability test was determined. The outcome is demonstrated below:

Table 1 Cronbach value of the six attributes about the perception of entrepreneurs in Lagawe,Ifugao.

\begin{tabular}{|c|c|c|c|c|c|c|c|}
\hline & & $\begin{array}{c}\text { A. } \\
\text { Entrepren } \\
\text { eurial } \\
\text { characteris } \\
\text { tic }\end{array}$ & $\begin{array}{c}\text { B. } \\
\text { Perceived } \\
\text { image of } \\
\text { entrepre } \\
\text { neurship }\end{array}$ & $\begin{array}{c}\text { C. } \\
\text { Motivatio } \\
\text { ns }\end{array}$ & $\begin{array}{l}\text { D. Barriers } \\
\text { in } \\
\text { pursuing } \\
\text { business } \\
\text { (non- } \\
\text { beneficiari } \\
\text { es) }\end{array}$ & $\begin{array}{c}\text { E. } \\
\text { Challenge } \\
\text { s in the } \\
\text { business } \\
\text { (for } \\
\text { beneficia } \\
\text { ries) }\end{array}$ & $\begin{array}{c}\text { F. } \\
\text { Entreprene } \\
\text { urial intent }\end{array}$ \\
\hline Cronb & $\begin{array}{l}\text { Raw } \\
\text { data }\end{array}$ & 0.966 & 0.712 & 0.935 & 0.971 & 0.956 & 0.954 \\
\hline $\begin{array}{l}\text { ach } \\
\text { Alpha }\end{array}$ & $\begin{array}{l}\text { Revised } \\
\text { data }\end{array}$ & 0.922 & 0.712 & 0.935 & 0.912 & 0.901 & 0.913 \\
\hline Remar & & Excellent & Good & Excellent & Excellent & Excellent & Excellent \\
\hline
\end{tabular}

Except in section B, all of the 121 metrics composed of six attributes have outstanding findings on internal consistency. Due to a high Cronbach value, which suggests that certain metrics are redundant, some elements have been excluded. Morgan (2017) notes that the development of scales is not harmed by duplicate items, although most writers say that with very high alpha, the scale needs to be shortened or certain items excluded. While a maximum alpha of .90 was preferred by many writers, some authors propose .91-.94 depending on the field of research. In this analysis, Cronbach alpha parameters of .91-.93 used by Nilsson, et al. (2017) were used to prevent repetition and omission of several objects. Means, the Mann-Whitney U test, and Spearman's rank-order correlation were used in this study through the help of SPSS. 
International Journal of Entrepreneurship, Business and Creative Economy (IJEBCE), Vol. 1 (2), 45-53

Are people in Ifugao, Philippines Entrepreneurial? Shedding light on entrepreneurial characteristics, motivations, challenges, and intentions among Ifugao

Client William Malinao

\section{Variables}

The variables in the study are entrepreneurial characteristics (need for achievement, locus of control, risk-taking propensity, tolerance for ambiguity, innovativeness), motivations, the perceived image of entrepreneurs, problems and challenges, training, seminars, and are considered independent variables, while Entrepreneurial intention as the dependent variable. Fig. 1 displays the relationship between the variables.

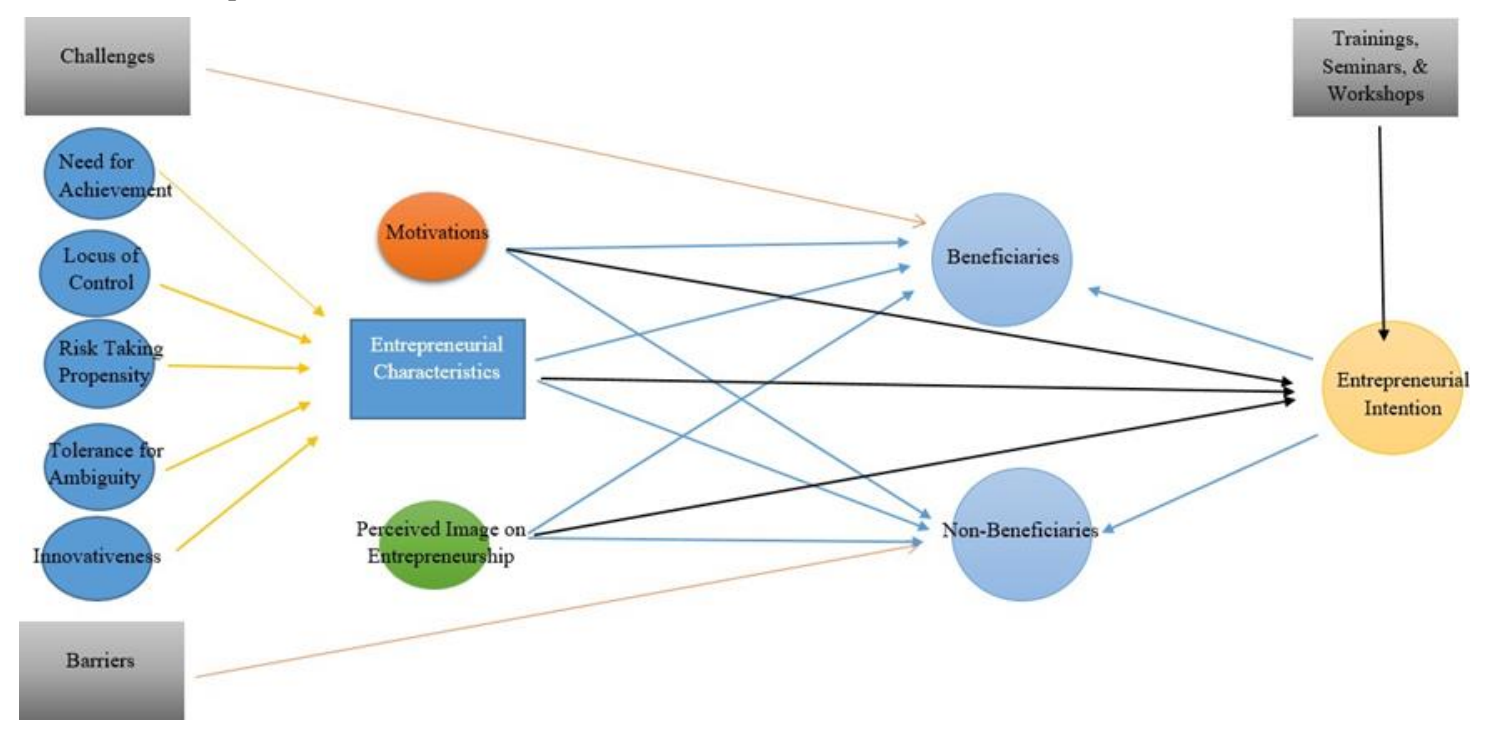

Figure 1. Schematic diagram of operational framework

\section{FINDINGS AND DISCUSSION}

Entrepreneurial Characteristics, Perceived Image, Motivations, Problems, and Challenges

Results from the study assert that people in Ifugao possesses the characteristics to be a good entrepreneur. Ifugao People perceived images of entrepreneurs are all very good except that entrepreneurs are stressed people who are always under struggle. It can be construed, therefore, that the respondents hold a brawny perception of the image they want to become.

Table 2 Descriptive Statistics

\begin{tabular}{|l|c|c|}
\hline \multicolumn{1}{|c|}{ Indicators } & Mean & $\begin{array}{c}\text { Descriptive } \\
\text { Interpretation }\end{array}$ \\
\hline Entrepreneurial Characteristics & 2.96 & Agree \\
\hline Perceived Image on Entrepreneurs & 2.86 & Agree \\
\hline Motivations & 2.98 & Agree \\
\hline Barriers in Doing Business (Non-Beneficiary) & 2.74 & Agree \\
\hline Challenges Encountered (beneficiary) & 2.98 & Agree \\
\hline Training, Seminars, and Workshops (Beneficiaries) & 3.02 & Agree \\
\hline
\end{tabular}

Autonomy and flexibility, the creation of wealth, a sense of achievement, and ambition are the primary reasons behind people in the Ifugao venture and/or wanted to pursue business. However, market competition, marketing strategies, finding a good place, capital, having the right technology 
International Journal of Entrepreneurship, Business and Creative Economy (IJEBCE), Vol. 1 (2), 45-53 Are people in Ifugao, Philippines Entrepreneurial? Shedding light on entrepreneurial characteristics, motivations, challenges, and intentions among Ifugao

Client William Malinao

and promotional tools are the reasons behind why they are discouraged to continue doing business. Also, respondents firmly claim that training, seminars, and workshops provided by different government agencies helped them on managing their business. However, as they grow their business and expand their markets, problems and challenges are becoming more complex than before.

On the other hand, respondents who are not beneficiaries or non-entrepreneurs, beginning capital, lack of knowledge, ideas and formal help to start a business, good market place, start-up paper works, and bureaucracy are the factors that hold them not to start their own business.

\section{Mann-Whitney U Test on Significant Differences}

Table 3 Significant difference on the entrepreneurial characteristics perceive image on entrepreneurship, motivations, entrepreneurial intent of people in Ifugao when group according to Beneficiary/Non-beneficiary.

\begin{tabular}{|c|c|c|r|r|r|r|}
\hline \multicolumn{2}{|c|}{ Category } & $\begin{array}{c}\text { Mean } \\
\text { Rank }\end{array}$ & $\begin{array}{c}\text { Mann- } \\
\text { Whitney } \\
\text { U }\end{array}$ & $\begin{array}{c}\text { Std. Test } \\
\text { Statistic }\end{array}$ & $\begin{array}{c}\text { Asymptotic } \\
\text { Sig. (2- } \\
\text { sided test) }\end{array}$ & Remarks \\
\hline \multirow{2}{*}{$\begin{array}{c}\text { Entrepreneurial } \\
\text { Characteristics }\end{array}$} & Beneficiary & 42.735 & 480.500 & -0.922 & 0.357 & Not Sig. \\
\cline { 2 - 7 } & $\begin{array}{c}\text { Non- } \\
\text { Beneficiary }\end{array}$ & 39.250 & & & & \\
\hline \multirow{2}{*}{$\begin{array}{c}\text { Perceived } \\
\text { Image }\end{array}$} & Beneficiary & 37.853 & 563.500 & 0.544 & 0.587 & Not Sig. \\
\cline { 2 - 8 } & $\begin{array}{c}\text { Non- } \\
\text { Beneficiary }\end{array}$ & 40.589 & & & & \\
\hline Motivations & Beneficiary & 44.088 & 457.500 & -1.052 & 0.293 & Not Sig. \\
\cline { 2 - 7 } & $\begin{array}{c}\text { Non- } \\
\text { Beneficiary }\end{array}$ & 38.879 & & & & \\
\hline \multirow{2}{*}{$\begin{array}{c}\text { Entrepreneurial } \\
\text { Intent }\end{array}$} & Beneficiary & 45.118 & 440.000 & -1.223 & 0.222 & Not Sig. \\
\cline { 2 - 7 } & $\begin{array}{c}\text { Non- } \\
\text { Beneficiary }\end{array}$ & 38.597 & & & & \\
\hline
\end{tabular}

Since the decision to reject the null hypothesis is violated. It is therefore concluded that the perception of beneficiaries and non-beneficiaries in Lagawe, Ifugao, Philippines do not differ in terms of entrepreneurial characteristics, perceived image, motivations, and entrepreneurial intent.

\section{Spearman's Rho Test on Significant Relationships}

Table 4 Significant Relationship between variables

\begin{tabular}{|c|c|c|c|c|c|c|c|}
\hline & & & $\begin{array}{c}\text { Entrepre } \\
\text { neurship } \\
\text { Characte } \\
\text { ristics }\end{array}$ & $\begin{array}{c}\text { Percei } \\
\text { ved } \\
\text { Image }\end{array}$ & $\begin{array}{l}\text { Motivat } \\
\text { ions }\end{array}$ & $\begin{array}{c}\text { Entrepre } \\
\text { neurship } \\
\text { Intent }\end{array}$ & $\begin{array}{c}\text { Training, } \\
\text { Seminars, } \\
\text { and } \\
\text { Workshops }\end{array}$ \\
\hline \multirow[t]{2}{*}{$\begin{array}{l}\text { Spear } \\
\text { man's } \\
\text { rho }\end{array}$} & \multirow{2}{*}{$\begin{array}{l}\text { Entrepre } \\
\text { neurship } \\
\text { Character } \\
\text { istics }\end{array}$} & $\begin{array}{l}\text { Correlation } \\
\text { Coefficient }\end{array}$ & 1.000 & $.401^{* *}$ & .202 & .167 & $.452^{* *}$ \\
\hline & & $\begin{array}{l}\text { Sig. } \\
\text { tailed) }\end{array}$ & & .000 & .075 & .140 & .000 \\
\hline
\end{tabular}


International Journal of Entrepreneurship, Business and Creative Economy (IJEBCE), Vol. 1 (2), 45-53 Are people in Ifugao, Philippines Entrepreneurial? Shedding light on entrepreneurial characteristics, motivations, challenges, and intentions among Ifugao Client William Malinao

\begin{tabular}{|c|c|c|c|c|c|c|c|}
\hline \multirow{2}{*}{\multicolumn{2}{|c|}{\begin{tabular}{|l} 
Perceived \\
Image
\end{tabular}}} & $\begin{array}{l}\text { Correlation } \\
\text { Coefficient }\end{array}$ & $.401^{* *}$ & 1.000 & $.390^{* *}$ & $.285^{*}$ & .333 \\
\hline & & $\begin{array}{ll}\text { Sig. } & (2- \\
\text { tailed) }\end{array}$ & .000 & & .000 & .011 & .000 \\
\hline \multirow{2}{*}{\multicolumn{2}{|c|}{$\begin{array}{l}\text { Motivatio } \\
\text { ns }\end{array}$}} & $\begin{array}{l}\text { Correlation } \\
\text { Coefficient }\end{array}$ & .202 & $.390^{* *}$ & 1.000 & $.227^{*}$ & .169 \\
\hline & & $\begin{array}{ll}\text { Sig. } & (2- \\
\text { tailed) }\end{array}$ & .075 & .000 & & .044 & .142 \\
\hline & $\begin{array}{l}\text { Trainings, } \\
\text { Seminars } \\
\text { and } \\
\text { Worksho } \\
\text { ps }\end{array}$ & $\begin{array}{l}\text { Correlation } \\
\text { Coefficient }\end{array}$ & $.452^{* *}$ & .333 & 169 & $.420^{* *}$ & 1.000 \\
\hline & & $\begin{array}{ll}\text { Sig. } & (2- \\
\text { tailed) }\end{array}$ & .000 & .000 & 142 & .000 & \\
\hline & \begin{tabular}{|l} 
Entrepre \\
neurial \\
Intent
\end{tabular} & $\begin{array}{l}\text { Correlation } \\
\text { Coefficient }\end{array}$ & .167 & $.285^{*}$ & $227^{*}$ & 1.000 & $420^{* *}$ \\
\hline & & $\begin{array}{|ll|}\begin{array}{l}\text { Sig. } \\
\text { tailed) }\end{array} & (2- \\
\end{array}$ & .140 & .011 & .044 & & .000 \\
\hline \multicolumn{7}{|c|}{ **. Correlation is significant at the 0.01 level (2-tailed). } & \\
\hline \multicolumn{7}{|c|}{ *. Correlation is significant at the 0.05 level (2-tailed). } & \\
\hline
\end{tabular}

The result indicates that there is no correlation between entrepreneurial characteristics and intent. However, there is sufficient evidence to suggest a weak relationship between perceived image and entrepreneurial intent. This is also the same on the relationship between motivation and intent. Lastly, training, seminars, and workshops initiated by the different government agencies are significantly correlated towards the development of entrepreneurial characteristics and intentions of Ifugao people to do business.

\section{Discussion}

Results reveal that Ifugao individuals think their skills/competencies would help them to operate an organization effectively. To become efficient, it is important to have a creative mind, to pursue good opportunities from unsatisfied needs, followed by proper preparation and hard work. Ifugao individuals turn these concepts into real goods and services that the world will access. They view themselves as risk-takers, but the number of rivals in the market quickly discourages them. Ignorance, laziness, and failure to enhance skills/skills/competencies are sources of organizational misfortunes.

The leading expectations of the participants engaging with an outstanding idea for an entrepreneur are a very strong focal point for discussion: they are the responsible individuals who can be role models for young people, they are the wealthy individuals who live extravagantly and they are the noble individuals who play a critical role in society. As eminent scholars have already said, role models play a powerful role in the development of human attitudes. Therefore, it is plausibly argued that these ideas, values, and perceptions of these prospective entrepreneurs are essential factors in the growth of one's entrepreneurial character, potential career attitude, and entrepreneurial intentions. 
International Journal of Entrepreneurship, Business and Creative Economy (IJEBCE), Vol. 1 (2), 45-53

Are people in Ifugao, Philippines Entrepreneurial? Shedding light on entrepreneurial characteristics, motivations, challenges, and intentions among Ifugao

Client William Malinao

Creation of opportunities that helps in maximizing wealth and economic development are some of the Entrepreneurial motivation among Ifugao individuals. Socialization can be seen to have a great effect and influence on the entrepreneurial aspirations of the respondents. An individual may be socialized formally and informally at home, at school, and in other spheres of interaction. The most influential influences influencing early socialization were family history, parental rolemodeling, formal schooling, and education; thus, the development of an attitude towards entrepreneurship.

In the mainstream, the mindset regarding the probability of an action to have an anticipated consequence and the subjective assessment of the consequences and rewards of that outcome affect behavioral intentions. The Theory of Expected Actions describes this phenomenon better. Although one's decision to become an entrepreneur may be believed to be premeditated by his desire to do so, this intention is only formulated soon before the final decision is made in most situations.

\section{CONCLUSION}

This paper establishes the relationship between entrepreneurial characteristics, motivations, the perceived image of entrepreneurs, training, seminars, and workshops on entrepreneurial intent among people in Lagawe, Ifugao, Philippines using Spearman's Rho Test. It determines that perceived image on entrepreneurs, motivations, training, seminars, and workshops are significantly correlated to the intentions of Ifugao people to be an entrepreneur. Hence, this paper recommends that government agencies should pay particular attention to positively influencing Ifugao's attitudes towards entrepreneurial activity and increasing their self- efficacy for creating a new firm. Business mind setting and business start-up should be the starting point of extension programs of the government and the university. In building, upgrading, and expanding infrastructural facilities such as rural highways to facilitate the transport of products, the government and the private sector could join hands. The government must guarantee access to funds for small and midsize enterprises by offering government subsidies and support through the development of a credit guarantee system, the settlement of collateral problems, and the provision of start-up processing and bureaucracy for young SMEs and local raw materials suppliers. The government should continue to subsidize the establishment of a standardized start-up and improve the growth capacity of businesses.

\section{LIMITATION \& FURTHER RESEARCH}

The study is limited to the extension programs initiated by the Ifugao State University and the Local Government Unit in Lagawe, Ifugao, Philippines. Future researchers might be interested in conducting a SWOT analysis in the functional areas of business (Management, Production and Operation, Marketing, and Finance) among businesses in the municipality. This would enable the government to determine what aspect of the business could be improved.

\section{REFERENCES}

Abdul, O.E. (2018). Entrepreneurial skills and growth of Small and Medium Enterprise (SMEs): A comparative analysis of Nigerian entrepreneurs and Minority entrepreneurs in the UK. International Journal of Academic Research in Business and Social Sciences Vol. 8, No. 5.

Amatori, F. (2006). Entrepreneurship in Theory and History. Business History Review, 80 (3). Pp. 615-617. 
International Journal of Entrepreneurship, Business and Creative Economy (IJEBCE), Vol. 1 (2), 45-53

Are people in Ifugao, Philippines Entrepreneurial? Shedding light on entrepreneurial characteristics, motivations, challenges, and intentions among Ifugao

Client William Malinao

Bosire, K., \& Nzaramba, K. (2013). Entrepreneurship Skills Development and Growth of Small and Medium Entreprises In Rwanda (Case Study: "Caplaki") 2007-2011. International Journal of Information Technology and Business Management. Vol.17. No.1.

Cities and Municipalities Competitive Index. (2019).

https://cmci.dti.gov.ph/pages/profile/?lgu=Lagawe, https://cmci.dti.gov.ph/pages/indicators/

Dugyon, E. (2016). The Extension Services of the Ifugao State University, the School Year 2012-2015: Basis for a Community Enhancement Program. International Journal of Science and Research (IJSR). Volume 5, Issue 6.

Entrialgo, M., Fernandez, E. \& Vazquez, C. (2000). Characteristics of managers as determinants of entrepreneurial orientation: some Spanish evidence", Enterprise and Innovation Management Studies, Vol. 1 No. 2. pp. 187-205.

Fong, B.W. (2018). Realizing the Full growth potential of SMEs in the Philippines. Inquirer.net. https://www.google.com/amp/s/business.inquirer.net/251036/realizingfullgrowth-potential-smes-ph/amp

Gürol, Y., \& Atsan, N. (2006). Entrepreneurial characteristics amongst university students", Education \& Training. Vol. 48 Issue 1 pp. 25 - 38: http://dx.doi.org/10.1108/00400910610645716 Harper, D. A. (2003). Foundations of Entrepreneurship and Economic Development: Taylor \& Francis e-Library, New York.

Kanchana, R.S., Divya, J.V \& Beegom, A.A. (2013). Challenges faced by the new entrepreneur. International Journal of Current Research and Academic Review. Volume 1, Number 3. Pp. 71-78

Lv, R.W., Lai, C., \& Liu, J. (2011). Entrepreneurial Capability Scale, and New Venture Performance: The Moderating Role of Entrepreneurship Education.

See, D.A. (2015). 43 businesses from PCCI Ifugao chapter. https://www.baguioheraldexpressonline.com/43-businesses-form-pcci-ifugao-chapter/

Zehra, N. (2016). Training \& Development Barometer for Effective Transformation of Organizational Commitment and Overall Performance in Banking Sectors of KPK, Pakistan: Qualitative study of Workforce of Bank of Khyber, International Journal of Academic Research in Business and Social Sciences, 6(6). Pp. 246-267. 